University of Nebraska - Lincoln

DigitalCommons@University of Nebraska - Lincoln

1997

\title{
Prior Beliefs and Voter Turnout in the 1986 and 1988 Congressional Elections
}

Stephen P. Nicholson

University of California - Davis

Ross A. Miller

University of Nebraska - Lincoln, rmiller10@unl.edu

Follow this and additional works at: https://digitalcommons.unl.edu/poliscifacpub

Part of the Political Science Commons

Nicholson, Stephen P. and Miller, Ross A., "Prior Beliefs and Voter Turnout in the 1986 and 1988 Congressional Elections" (1997). Faculty Publications: Political Science. 52.

https://digitalcommons.unl.edu/poliscifacpub/52

This Article is brought to you for free and open access by the Political Science, Department of at DigitalCommons@University of Nebraska - Lincoln. It has been accepted for inclusion in Faculty Publications: Political Science by an authorized administrator of DigitalCommons@University of Nebraska - Lincoln. 


\title{
Prior Beliefs and Voter Turnout in the 1986 and 1988 Congressional Elections
}

\author{
Stephen P. Nicholson, University of California, Davis \\ Ross A. Miller, Santa Clara University
}

The costs of political information differ between and among elections. In those elections where information costs are high, voters should rely on information from previous elections. Although research on voter choice has long recognized that voters use past information in their assessments of candidates, studies of voter turnout are solely concerned with information available in the current election. Specifically, the closeness of elections is a central concern in rational actor models of voter turnout. As such, these studies neglect the effects of prior electoral competitiveness on citizens' decisions to vote. In this study we propose that actors rely on prior beliefs when deciding to vote in information-poor elections. Controlling for information available in the current election, we explore this possibility in the 1986 and 1988 House elections and find that prior beliefs have a significant effect on turnout.

The closeness of elections is central to rational actor approaches to voter turnout. In the dominant rational choice approach, the calculus of voting (Riker and Ordeshook 1968), citizens base their decisions to vote, in part, on the probability that their vote will affect the electoral outcome. However, scholars have implicitly assumed that the amount of information available to voters in assessing the closeness of elections is equivalent across and among elections. This assumption is problematic since the amount of information available in an election varies with office and the profile of the contest. Aldrich (1993: 262) observes that "political scientists have studied turnout almost exclusively in high profile contests, in which case information acquisition (if not processing) costs can safely be considered small." In contrast to highly visible presidential candidates, those running for the

NOTE: An earlier draft of this article was presented at the Western Political Science Association Annual Meeting, Albuquerque, New Mexico, March 10-12, 1994. We would like to acknowledge the helpful comments of Nathaniel Beck, Scott Gartner, Gary Jacobson, Robert Jackman, Gary Segura, Randy Siverson, Roger Rose, and Michael Wilkening. In addition, we would like to thank Walter Stone and the anonymous reviewers of the Political Research Quarterly.

R.A. Miller, affiliation 2012, University of Nebraska-Lincoln; rmiller10@unl.edu. 
House, especially challengers, are relatively unknown (Jacobson 1992; chapter 5; Mann and Wolfinger 1980; Stokes and Miller 1962). The general low visibility of House races, coupled with low challenger resources (Abramowitz 1991; Jacobson and Kemen 1983; Mann and Wolfinger 1980), makes these elections quite distinct from each other and from elections for higher office (e.g., president, governor).

Because most House elections are information-poor, it is unlikely that citizens primarily base their decisions to vote on the perceived closeness of a race. Of course, when available, the closeness of an election is critical new information. The decision to vote in House elections, however, should be recognized as a repeated choice in which citizens rely on prior beliefs about the electoral competitiveness of the district in which they reside. Prior beliefs are formed from past experience and updated when new information is available. Absent new information, a congressional district that was hotly contested in the prior election should alert citizens that the incumbent is vulnerable in the current election. Likewise, a prior election in which the incumbent won by a large margin should inform citizens that their vote will not be decisive to the outcome of the subsequent election. In short, because political information is a costly good, especially in information-poor environments, a district's prior electoral history provides important contextual information, or prior beliefs, about the general competitiveness of elections.

In this article we develop and test a framework of prior beliefs. We argue that individuals form prior beliefs about electoral competitiveness and use this information when deciding to vote. Furthermore, this information is used even when citizens are knowledgeable about the current election. Voters form prior beliefs about closeness and update these beliefs when new information is acquired. We begin with a brief discussion of the theoretical and empirical issues surrounding rational actor theories of turnout, and then present our framework of prior beliefs. We then evaluate the effect of prior and updated beliefs on turnout in the 1986 and 1988 House elections, using a research design that specifies ex ante measures of a competitive election. We do so in order to represent accurately the decisionmaking environment actors face when updating their beliefs. Moreover, while most studies look at cross-sectional variation in levels of turnout, we examine tumout over time (see Grofman 1993).

\section{RATIONAL ACTORS AND TURNOUT}

In 1957, Downs published his expected utility theory of voting. In its original form, this theory posits that decisions to vote hinge on two factors: the probability that a single vote will affect the outcome of an election and the costs associated with voting. Because the probability that one vote 
will significantly affect the outcome of an election is normally quite small (discounting the benefits of voting), Downs concludes that, for most elections, the costs will exceed the benefits. Therefore, according to Downs, most decisions to vote are irrational. In order to explain this seemingly irrational act by many voters, Downs suggests that perhaps people vote because they wish to see democracy continue.

Riker and Ordeshook (1968) reformulated this approach in two ways. First, they expanded Downs' argument that citizens vote because of their wish to see democracy continue by suggesting that people vote for a variety of reasons, including civic duty, "allegiance to the political system," "affirming a partisan preference," "the satisfaction of deciding," and efficacy (1968: 28). Second, Riker and Ordeshook reformulated the probability that a single vote will influence the outcome of an election as "a function of the estimated closeness of the vote" (1968: 32). These revisions of expected utility theory led Riker and Ordeshook to conclude that voting is a rational act (1968: 38).

While most of the empirical research at the aggregate level finds a weak to modest positive relationship between closeness and turnout (Barzel and Silberg 1973; Cox and Munger 1989; Crain, Leavens, and Abbot 1987; Gray 1976; Patterson and Caldeira 1983), individual-level analyses conclude that the relationship is weak at best, and possibly trivial (Ferejohn and Fiorina 1974; Foster 1984). Although Ferejohn and Fiorina (1974) offer an alternative to the calculus of voting, the minimax regret criterion, Blais et al. (1995) found that it has no independent effect on turnout when tested against components of the calculus of voting.

In response to the calculus of voting's modest findings, scholars have used either implicitly or explicitly the strategic politicians' framework of electoral behavior to address the relationship between closeness and turnout (Aldrich 1993; Jackman 1993). According to Jacobson and Kernell (1983), it is the reaction of strategic politicians to national conditions which explains House election outcomes. Although Jacobson and Kernell (1983) apply this framework to electoral outcomes, several studies have looked at strategic politicians, or explanations consistent with this approach and their effect on turnout. For example, Dawson and Zinser's (1976) study of the 1972 congressional elections provides evidence that total expenditures - a common indicator of elite activity - has a positive and significant impact on turnout. Cox and Munger's (1989) test of strategic politicians and voter turnout in the 1982 congressional elections suggests that total candidate expenditures, controlling for the effects of closeness, has a strong effect on turnout. A strong relationship between elite behavior and turnout is also apparent in gubernatorial elections (Patterson and Caldeira 1983). Thus, studies that posit a strategic politician's argument generally conclude that closeness matters, but its effects on turnout are of second- 
ary importance compared to the influence of elite activity.

In addition to the top-down influence of strategic politicians, we offer a framework of analysis that builds upon the calculus of voting. Specifically, we examine prior beliefs, in this instance knowledge of past elections, and how they affect voter perceptions of the closeness of current elections. We begin with a brief discussion of voter information in House elections and its implications for voter turnout.

\section{INFORMATION IN HOUSE ELECTIONS}

The cost of information in House elections is typically much higher than in senatorial or presidential elections. The greater media coverage and candidate advertising found in elections for higher office attest to this differential. Numerous studies at the individual level consistently demonstrate that voters are ill-informed about House elections (for example, see Mann and Wolfinger 1980; Stokes and Miller 1962). However, when individuals are able to identify candidates, incumbents are much better known (Mann and Wolfinger 1980; Zaller 1992). While recall of candidates' names is generally low, incumbents are more than twice as likely to be correctly named (Jacobson 1992: 118). The general inability to name the challenger, the more dynamic ingredient of competitive House elections, suggests that voters often have little knowledge of the election in which they are participating.

Why do voters have so little knowledge about House challengers? In deciding whom to vote for in a House election, Aldrich (1993) notes that when the challenger is unknown, voters

appear to construct decision rules about whom to support from [an] asymmetric informational base. ... Since the incumbent has an unusually high degree of control over this readily obtainable information in House elections, it should be no surprise that the rationally ill-informed voter typically decides that the incumbent is doing at least an adequate job. (Aldrich 1993: 262, f.18)

Aldrich's conception of voting in House elections is further elaborated by the logic of McCubbins and Schwartz's (1984) theory of "fire alarms" and "police patrols." Voters, like members of Congress in their oversight of the bureaucracy, may prefer fire alarms - being informed by others of a problem - to a police patrol system that involves active monitoring. In elections, challengers subsidize information costs (e.g., attempt to convince voters with negative information about the incumbent). Thus, absent a well-funded, high quality candidate to convince voters that the incumbent is shirking her responsibility, voters rationally choose the status quo. 


\section{PRIOR BELIEFS AND VOTER TURNOUT}

The implications of low information contests, such as House elections, are not examined in empirical tests of rational actor models of voter turnout (Aldrich 1993: 262). Futhermore, these empirical tests have "been hampered by an overly narrow interpretation of the theoretical models" (Aldrich 1993: 274). The calculus of voting model implicitly assumes that each election is an isolated event and that decisions to vote are made solely on estimates of the current election. In the Riker and Ordeshook model (1968: 28), the decision to vote is represented by the following equation:

$$
\mathrm{R}=\mathrm{PB}-\mathrm{C}+\mathrm{D},
$$

where $\mathrm{R}$ is the reward that an individual receives for voting; $\mathrm{P}$ is the probability that, by voting, an individual will bring about the benefit of having his preferred candidate elected; $B$ is the difference in benefits an individual receives from the success of his preferred candidate over his less preferred one; $\mathrm{C}$ is the cost of voting; and $\mathrm{D}$ is a sense of citizen duty (or the non-instrumental effects of voting such as efficacy).

Based on empirical findings at the individual level, we relax the assumption that voters have information about challengers. Although Aldrich's discussion of asymmetric voting choice is a plausible explanation for how voters use information shortcuts in calculating B, it cannot explain how voters calculate the $\mathrm{P}$ term. If a rational voter does not have information about the challenger, or does not even know if a challenger is running, it is likely that she cannot calculate B. Holding C and D constant, if we assume that voters have no information about the challenger (are unable to calculate B), it is unlikely that they will be able to calculate P.

In low information elections where knowledge of B is absent, we assume that $\mathrm{P}$ is primarily derived from prior beliefs regarding the closeness of elections. ${ }^{1}$ In the absence of fire alarms, therefore, we propose that $\mathrm{P}$ is derived from $\mathrm{P}_{\mathrm{t}-1}$, prior beliefs about closeness. Although prior beliefs about the closeness of elections does not solve the empirical problem that $\mathrm{P}$ is essentially zero, they provide a solution to how voters estimate $\mathrm{P}$ in information-poor environments, such as House elections.

Prior beliefs extend the basic Riker and Ordeshook (1968) model to give potential voters expectations about the competitiveness of their congressional district. The inclusion of prior beliefs places voters within a larger context or game in which they must decide whether to vote based on $\mathrm{N}$

\footnotetext{
${ }^{1}$ While prior beliefs are based on strategic behavior as found in game theory, they are nonetheless expectations and not an actual game. Thus, their inclusion is appropriate to the calculus of voting which is decision theoretic.
} 
previous elections. These expectations are based on past strategic behavior (what voters did in prior elections) and are updated by new information (the closeness of the current election). According to Morrow (1994: 162), "When actors are uncertain, they use new information to update their beliefs about underlying states of the world. Rarely is new information decisive for judging the state of the world. Instead, it shifts the player's judgment about the likelihood of different states." Although voters have prior beliefs about all elections - not just those in which information is scarce - the relative importance of prior beliefs should be greater when new information is scarce. ${ }^{2}$ Absent new information, in elections in which information is not abundant, voters should decide whether to vote based on prior information about the closeness of elections in their congressional district.

Moreover, prior beliefs about the competitiveness of elections parallels the vast literature on retrospective voting. This theory of rational voting is contingent on voters using past information about the incumbent's performance to determine their vote in the current election (Downs 1957; Fiorina 1981; Kramer 1971). In determining the candidate differential, Downs (1957) asserts that this information is based, in part, on evaluations of the party in power. Building on Downs, Fiorina (1981) finds that information about the performance of the incumbent party affects voter behavior in the current election. For example, poor economic conditions at time $t$ will have the effect of reducing support for an incumbent (or the party of the incumbent) at time $t+1$. According to Fiorina (1981: 12), the simple but powerful logic behind retrospective voting is that "knowledge of past performance is cheaper to acquire (it is acquired automatically, in effect) than knowledge of future plans."

Although Downs and Fiorina are concerned with the effect of past policies in determining vote choices, the logic of the argument is consistent with the decision to vote. In order to reduce the high costs associated with voting in low information campaigns, voters use prior beliefs about the state of the world-the competitiveness of their congressional district-to calculate expected closeness. In districts with a history of close elections, potential voters should be more likely to cast their ballot than potential voters in those districts with a history of lopsided election outcomes. Ceteris paribus, those in competitive districts are more likely to vote because they believe that the upcoming election will be close. Thus, information about past elections should influence individuals'

${ }^{2}$ The acquisition of new information and its relative importance to updating beliefs about the state of the world is derived from Bayes's Theorem. For a good discussion of Bayesian updating and prior beliefs see Hirshleifer and Riley (1992) and Morrow (1994, chap. 6). 
beliefs about the closeness of the current election, and consequently their decisions to vote.

\section{A TEST OF PRIOR AND UPDATED BELIEFS}

In this section we present and evaluate the explanatory power of four measures of prior and updated beliefs about the closeness of elections. An obvious indicator of prior beliefs about the competitiveness of House elections is the absolute value of the margin of victory achieved by the winning candidate in the prior election. We expect that if a candidate wins the previous election by a large margin, citizens are more likely to believe that the upcoming election will result in a lopsided victory for the incumbent. Because the probability of affecting the outcome in the current election is perceived as very low, we expect a lower aggregate level of turnout. However, if the prior election was close, voters are more likely to believe that the incumbent is vulnerable in the current election. Thus, a prior close election should increase turnout in the current election.

A second measure of prior beliefs is the defeat of an incumbent in the prior election. Incumbents are rarely defeated (about 3 percent of the time), and when they are, we expect citizens to use this information in deciding whether to vote in the next election. As with the effects of prior closeness, the defeat of an incumbent in the prior election is likely to inform voters that either (1) the seat is unsafe and therefore likely to be hotly contested in the future or (2) the candidate is a first term member of Congress and likely to be in a competitive race. Consequently, citizens should be more likely to vote in the election following the defeat of an incumbent.

Although citizens use prior beliefs in their decisions to vote, these beliefs are updated when new information about the closeness of an election is available. In order to examine this question more directly, we use indicators that are consistent with the information available to citizens prior to the election. Although the ex post measure of closeness used in many studies-the actual margin of victory-is a proxy for the perceived closeness of elections (Barzel and Silberg 1973: Berch 1993; Cox and Munger 1989: Patterson and Caldeira 1983; Settle and Abrams 1976), it does not accurately capture the information individuals use when updating their beliefs. So, unlike other studies that do not use a Bayesian framework, we use measures of information that are available to citizens prior to deciding to vote.

In general, the use of ex post measures does not properly depict an actor's decision-making environment. In studies of voter turnout the measure of actual closeness in an election is only available to voters after the election has occurred. In contrast, a strategic politician's approach emphasizes information voters have available to them before they vote. By 
employing ex ante factors, it is possible to predict turnout. Aside from the fact that an ex post measure does not capture the information citizens had available to them at the time they decided whether to vote, it implicitly assumes that citizens have near-complete information prior to the decision of whether to vote. As Gartner (1993: 367) argues in his study of Carter's decision to rescue hostages from Iran, ex post measures "over-estimate the certainty with which decision makers knew the outcome of policy choices." Therefore, to test properly our model of decision-making based on updated beliefs it is important to depict accurately the information available to actors at the time the decision is made. For these reasons, we use the strategic politicians framework to reconceptualize the central concern of rational choice empirical models - the closeness of elections.

The cost of information and updating beliefs is contingent on the behavior of strategic politicians. Specifically, the quality of candidates and their campaigns are the type of information voters use when they update their beliefs about the competitiveness of an election. As mentioned, new information is costly in the information-poor environment of House elections, especially regarding challengers. Nonetheless, information available to voters varies with the characteristics of each election (candidates and campaigns). Empirical studies have found that information in House elections varies according to factors such as challenger spending (Zaller 1992) and whether the contest is an open seat (Mann and Wolfinger 1980). Most often, candidate expenditures and candidate quality affect the competitiveness of an election Oacobson and Kernell 1983; Jacobson 1990). Voters update their prior beliefs about closeness based on the actions of those candidates running for office and their campaign organizations.

Whether candidates subsidize the costs of information that voters use in deciding to vote, and for whom, is contingent on the type of candidate that chooses to run. In Jacobson and Kernell's (1983) strategic politicians framework, the strategic decisions of quality challengers - those with prior office holding experience - affect the dynamics of the election. Quality challengers change the incentives for incumbents, inducing them to wage harder-fought campaigns. Further, the presence of these challengers affects the incentives of potential contributors to give to both candidates. In this way, high quality candidates subsidize the high costs of information through advertising and direct mobilization. Moreover, they induce incumbents to do the same.

Although Jacobson and Kernell (1983) found that prior officeholding experience had a significant effect on electoral outcomes, we apply this approach to voter turnout. The higher the quality of the challenger, the greater the probability that the challenger will have the resources to inform and 
mobilize supporters. Increasing levels of challenger quality should therefore be associated with higher turnout.

Elections with higher quality challengers are also characterized by higher campaign spending (Mann and Wolfinger 1980). Following Dawson and Zinser (1976), Cox and Munger (1989) and Patterson and Caldeira (1983), we also control for changes in the level of overall spending between the current and previous election in order to capture changes in elite activity. Increases in campaign spending should be associated with relatively higher levels of turnout.

To evaluate the effects of prior and updated beliefs on turnout, we

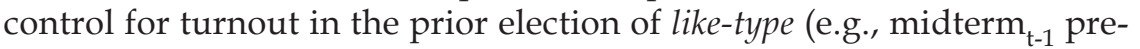
dicting midterm ${ }_{t}$ ). The inclusion of a lagged turnout variable provides a baseline to evaluate the effect of our measures of prior beliefs on turnout in the current election. This measure also controls for demographic and institutional variables that affect turnout levels across districts (Berch 1993).

For controls, we include variables indicating the presence of coterminous senatorial and presidential elections to take into account the effects of these races. We also control for those congressional races which are for open seats because these elections have a greater percentage of better known candidates, and therefore would be expected to have higher levels of turnout.

\section{Analysis}

Given the above discussion, we evaluate the following four hypotheses:

H1: The closer the win-loss margin of the prior election, the higher the level of turnout in the current election.

$\mathrm{H} 2$ : The defeat of an incumbent in the prior election will increase turnout in the current election.

H3: The greater the (positive) difference in the quality of the challenger between the current and prior elections, the higher the level of turnout in the current election.

H4: The greater the (positive) difference in the amount of spending of challengers between the current and prior elections, the higher the level of turn-out in the current election.

To test these hypotheses, we estimate the following OLS regression equation:

TURNOUT $=b_{0}+b_{1}$ MARGIN $_{t-1}+b_{2}$ INC DEFEAT $_{\mathrm{t}-1}+b_{3}$ AQUALITY $+b_{4}$ $\triangle$ SPENDING $+b_{5}$ TURNOUT $_{\mathrm{t}-2}+\mathrm{b}_{6}$ SENATE $+\mathrm{b}_{7}$ PRESIDENT $+\mathrm{b}_{8}$ OPEN $+e$

where TURNOUT is the total number of votes cast in the 1986 and 1988 
Congressional elections divided by the age-eligible population; ${ }^{3}$ MAR$\mathrm{GIN}_{\mathrm{t}-1,1}$, is the margin of victory in the prior election. ${ }^{4}$ INC DEFEAT $\mathrm{t}-1$, is coded as one (1) if the incumbent in the prior election was defeated and zero (0) if not; $\triangle$ QUALITY is the difference between the quality of the challenger in the current election and the quality of the challenger in the previous election. The quality of candidates is coded zero (0) if the candidate has not held prior elective office, one (1) if the candidate has held prior political office, ${ }^{5} \triangle$ SPENDING is operationalized as the percentage difference in spending between the current and prior elections; ${ }^{6}$ TURNOUT $_{t-2}$ is TURNOUT lagged two elections; SENATE is a dummy variable coded as one (1) if there was a Senate race and zero (0) if there was not; PRESIDENT is a dummy variable, coded as one (1) if there was a presidential election that year and zero ( 0 ) if it was a midterm election; OPEN is a dummy variable with one (1) representing an open seat and zero (0) indicating that the contest has an incumbent; and e represents the error term.

To be included, elections had to have a minimum of two candidates (e.g., we exclude unopposed elections) who spent at least \$5,000 each. The resulting data set has 477 observations for the 1986 and 1988 congressional elections. Table 1 displays the estimates of our model.

The results of the regression analysis are consistent with our expectations. The model accounts for 88 percent of the variation in turnout rates and is statistically significant at the $p<0.01$ level. The two indicators of prior electoral competitiveness, MARGIN $\mathrm{t}_{\mathrm{t}-1}$ and INC DEFEAT $\mathrm{I}_{\mathrm{t}-1}$, are significant and in the predicted direction. The coefficient for the lagged incumbent defeat variable, INC DEFEAT, is $0.015(p<0.05)$ suggesting that, on average, a defeat of an incumbent in the prior election increases turnout in the current election by 1.5 percent. The coefficient for the closeness of the prior election, MARGIN $\mathrm{t}-1_{1}$, is also significant $(p<0.01)$ and in the predicted direction. ${ }^{7}$ Substantively, the coefficient of -0.05 implies that, on average, a one percent decline in the margin of victory in the preceding

${ }^{3}$ Turnout figures were provided by the International Consortium for Political and Social Research, University of Michigan. Age-eligible population figures are based on U.S. Census Bureau data, following an estimation procedure used by Powell (1986) and Jackman (1987).

${ }^{4}$ We use the following equation to estimate MARGIN $_{t-1}$ :

$$
\mid 0.5 \text { - (votesA/(votesA+votesB)) |, }
$$

where $\mathrm{A}$ and $\mathrm{B}$ represent the candidates who received the highest number of votes in the election.

${ }^{5}$ We thank Gary Jacobson for providing this information.

${ }^{6}$ Data on overall levels of spending are from Federal Election Commission estimates.

${ }^{7}$ Because we subtract the actual percentage difference from 0.5 (which represents the closest possible election), the lower the value, the closer the election. 
election $\left(\right.$ time $\left._{\mathrm{t}-1}\right)$ increases turnout by about 0.5 percent in the current election $\left(\right.$ time $_{\mathrm{t}}$ ).

As expected, turnout in the prior election of like type, TURNOUT $\mathrm{t}_{\mathrm{t}-2}$ is a strong predictor of turnout in the current election. The sign of the coefficient is positive and significant well beyond the $p<0.01$ level. The large size of the coefficient suggests that turnout in congressional districts is

Table 1

OLS Estimates of the Effect of Prior and Updated Beliefs on Turnout in the 1986 and 1988 House Elections

$\begin{array}{lcc}\text { Variable } & \text { Coefficient } & \text { T-ratio } \\ \text { MARGIN }_{\mathrm{t}-1} & -0.054 & 2.74^{* *} \\ \text { INC DEFEAT }^{*} & 0.015 & 1.67^{*} \\ \triangle \text { QUALITY }^{\text {SPENDING }} & 0.003 & 0.90 \\ \text { TURNOUT }_{\mathrm{t}-2} & 0.003 & 2.59^{* *} \\ \text { SENATE }_{\text {PRESIDENT }} & 0.895 & 38.28^{* *} \\ \text { OPEN - } & 0.016 & 4.02^{* *} \\ \text { INTERCEPT } & 0.032 & 7.42^{* *} \\ & 0.006 & 0.98 \\ \end{array}$

$\mathrm{R}^{2}=0.88 \quad \mathrm{~F}=425^{* *} \quad \mathrm{~N}=477$

*significant at the 0.05 level (one-tailed test); ${ }^{* *}$ significant at the 0.01 level (onetailed test).

rather stable across elections. The two control variables of electoral context, a coterminous senatorial or presidential election, have a positive effect on turnout levels. The variable SENATE has a coefficient of $0.016(p<$ 0.01 ) which suggests that the presence of a Senate election increases turnout levels 1.6 percent. Likewise, the variable PRESIDENT is highly significant $(p<0.01)$ and in the predicted direction. The coefficient $(0.032)$ suggests that, on average, the presence of a presidential election increases turnout by approximately 3.2 percent. Surprisingly, the control for open seats is not distinguishable from zero $(p<0.324)$.

The results of the strategic politicians variables are mixed. Although the coefficient for $\triangle$ QUALITY is in the predicted direction, it is not statistically significant. On the other hand, differences in spending between the current and the prior election have a positive, significant effect on turnout. ${ }^{8}$ This result supports Cox and Munger's (1989) finding that total spending is highly related to turnout.

${ }^{8}$ One possible explanation for these mixed results is that increases in the quality of candidates are associated with increases in overall spending. However, the correlation between these two variables is only 0.15 . 
The cross-sectionally dominant nature of our pooled design is a potential concern about the robustness of our results. However, regression diagnostics for heteroscedasticity ${ }^{9}$ and influential outliers ${ }^{10}$ suggest that the results are robust.

\section{CONCLUSION}

We have argued that citizens use prior beliefs regarding the closeness of elections when deciding whether to vote. In reasoning under uncertainty, especially in information-poor environments such as House elections, voters rely heavily on information regarding their district's prior electoral competitiveness to assess its general level of competitiveness. This information, in turn, forms voters' prior beliefs about the expected utility of voting successive elections. If presented with low cost information, voters update their beliefs about the closeness of an election.

The robust nature of our measures, controlling for other explanations, suggests that voters in low information elections use prior beliefs when making decisions about whether to vote. Both of our indicators of prior beliefs, the effect of prior closeness and the defeat of an incumbent in the last election, indicate that voters use prior beliefs about the competitiveness of elections. Not surprisingly, we also found that voters update their beliefs about the closeness of elections through higher turnout levels when candidate spending is high. Thus, voters form prior beliefs about

${ }^{9} \mathrm{An}$ examination of the residuals plotted against the fitted values indicate a homoscedastic distribution. As a second test of heteroscedasticity, we regressed the absolute values of the residuals on all independent variables. Three variables had significant coefficient estimates $(P<0.05$ using a two-tailed test): turnout in the prior election, the presence of a presidential election, and the presence of a senate election. These estimates indicate that the magnitude of the residuals for the model as a whole varies systematically by the values of these variables, independent of the effects of the other variables in the model. The standard errors for these variables will be inflated, and therefore the t-ratios will be negatively biased. To assess the possible biasing effects of heteroscedasticity on the results presented in Table 1, we reestimated the model using median regression (Narula and Wellington 1982). The estimates from this procedure were virtually identical to those obtained using ordinary least squares.

${ }^{10} \mathrm{~A}$ second concern is the effect of outliers on the estimates presented in Table 1. We identified three possible influential points. To assess the effect they had on the estimates obtained above, we ran separate regressions controlling for these cases singly and jointly. The estimates we obtained were substantively very similar to those presented in Table 1. As an additional check, we reestimated the model using robust regression, which takes into account the effect of each observation of the overall results (see Berk 1990). Once again, the estimates were very similar to those from the ordinary least squares regression. 
the competitiveness of their congressional district and update these beliefs when new information is readily available.

However, further research on voters prior beliefs about the closeness of elections and the decision to vote is needed at the individual level. Since our research is based on aggregate-level data, our findings are only suggestive of individual-level behavior. A study similar to that of Blais et al. (1995) in which competing hypotheses are tested jointly would be useful for this purpose.

An area we hope to explore in later research is the possible objection that the relationship between our measures of prior beliefs about electoral competitiveness and voter behavior are mediated. Although we control for the effects of strategic politicians, local media may be responsible for informing voters of past electoral outcomes. For example, Iyengar and Kinder (1987: 104) report "a huge and politically consequential priming effect" on candidate feeling thermometers when television emphasizes positive candidate qualities. Similar effects might be found if local media emphasize the vulnerability of a candidate following an election in which an incumbent has been defeated or won by a small margin.

In contrast to approaches that use an ex post measure of closeness, we provide more reasonable measures to account for information voters use to make decisions. Our research design avoids the possible bias in ex post measures of closeness and therefore advances empirical studies of voter voter turnout by focusing on the closeness of elections in a predictive manner. By modeling voters' prior beliefs and the behavior of strategic politicians, this design provides a richer notion of the decision to vote in the lower-information environment that characterizes House elections.

\section{REFERENCES}

Abramowitz, Alan I. 1991. Incumbency, Campaign Spending, and the Decline of Competition in U.S. House Elections. Journal of Politics 53: 34-56.

Aldrich, John H. 1993. Rational Choice and Turnout. American Journal of Political Science 37: 246-278.

Barzel, Yoram, and Eugene Silberg. 1973. Is the Act of Voting Rational? Public Choice 16: 51-58.

Berch, Neil. 1993. Another Look at Closeness and Turnout: The Case of the 1979 and 1980 Canadian National Elections. Political Research Quarterly 46: 421-432.

Berk, Richard A. 1990. A Primer on Robust Regression. In: John Fox and J. Scott Long, eds., Modern Methods of Data Analysis. Newbury Park, Calif.: Sage.

Blais, Andre, Robert Young, Christopher Fleury, and Miriam Lapp. 1995. Do People Vote on the Basis of Minimax Regret? Political Research Quarterly 48: 827836.

Campbell, Angus, Philip E. Converse, Warren E. Miller, and Donald E. Stokes. 1960. The American Voter. New York: Wiley. 
Cox, Gary W. 1988. Closeness and Turnout: A Methodological Note.Journal of Politics 50: 768-775.

Cox, Gary W, and Michael C. Munger. 1989. Closeness, Expenditures, and Turnout in the 1982 House Elections. American Political Science Review 83: 217-232.

Crain, Mark, Donald R. Leavens, and Lynn Abbot. 1987. Voting and Not Voting at the Same Time. Public Choice 53: 221-229.

Dawson, Paul A., and James E. Zinser. 1976. Political Finance and Participation in Congressional Elections. Annals of the American Academy of Political and Social Science 425: 59-73.

Downs, Anthony. 1957. An Economic Theory of Democracy. New York: Harper \& Row.

Ferejohn, John A., and Morris P Fiorina. 1974. The Paradox of Not Voting: A Decision Theoretic Analysis. American Political Science Review 68: 525-536.

Fiorina, Morris P 1981. Retrospective Voting in American National Elections. New Haven: Yale University Press.

Foster, Carroll B. 1984. The Performance of Rational Voter Models in Recent Presidential Elections. American Political Science Review 78: 678-690.

Gartner, Scott S. 1993. Predicting the Timing of Carter's Decision to Initiate a Hostage Rescue Attempt: Modeling A Dynamic Information Environment. International Interactions 18: 365-386.

Gray, Virginia. 1976. A Note on Competition and Turnout in the American States. Journal of Politics 38: 153-158.

Grofman, Bernard. 1993. Is Voter Turnout the Monster that Ate Rational Choice? In: Bernard Grofman, ed., Information, Participation, and Choice: An Economic Theory of Democracy in Perspective. Ann Arbor: University of Michigan Press.

Hirshleifer, Jack, and John G. Riley. 1992. The Analytics of Uncertainty and Information. Cambridge: Cambridge University Press.

Iyengar, Shanto, and Donald R. Kinder. 1987. News That Matters: Television and American Opinion. Chicago: University of Chicago Press.

Jacobson, Gary C. 1990. The Electoral Origins of Divided Government: Competition in U.S. House Elections, 1946-1988. Boulder, Colo.: Westview Press.

---. 1992. The Politics of Congressional Elections, 3rd ed. New York: Harper Collins.

Jacobson, Gary C., and Samuel Kemell. 1983. Strategy and Choice in Congressional Elections, 2nd ed. New Haven: Yale University Press.

Jackman, Robert W. 1987. Political Institutions and Voter Turnout in the Industrial Democracies. American Political Science Review 81: 405-424.

---. 1993. Rationality and Political Participation. American Journal of Political Science 37: 279-290.

Kramer, Gerald H. 1971. Short-Term Fluctuations in U.S. Voting Behavior, 18961964. American Political Science Review 65: 131-143.

Mann, Thomas E., and Raymond E. Wolfinger. 1980. Candidates and Parties in Congressional Elections. American Political Science Review 74: 617-632.

McCubbins, Matthew D., and Thomas Schwartz. 1984. Congressional Oversight Overlooked: Police Patrols Versus Fire Alarms. American Journal of Political Science 2: 165-179.

Morrow, James D. 1994. Game Theory for Political Scientists. Princeton, N.J.: Princeton University Press. 
Narula, S. C., and J. E Wellington. 1982. The Minimum Sum of Absolute Errors Regression: A State of the Art Survey. International Statistical Review 50: 317-326.

Patterson, Samuel C., and Gregory A. Caldeira. 1983. Getting out the Vote: Participation in Gubernatorial Elections. American Political Science Review 77: 675-689.

Powell, G. Bingham, Jr. 1986. American Voter Turnout in Comparative Perspective. American Political Science Review 80: 17-43.

Riker, William, and Peter Ordeshook. 1968. A Theory of the Calculus of Voting. American Political Science Review 62: 25-42.

Settle, Russell E, and Buron A. Abrams. 1976. The Determinants of Voter Participation: A More General Model. Public Choice 27: 81-89.

Stokes, Donald E., and Warren E. Miller. 1962. Party Government and the Saliency of Congress. Public Opinion Quarterly 26: 531-546.

Zaller, John R. 1992. The Nature and Origins of Mass Opinion. Cambridge: Cambridge University Press.

Received: September 18, 1995; accepted for publication: February 26, 1996. 